\title{
KINERJA REKSADANA TERPROTEKSI SYARIAH DENGAN INDEKS SHARPE, TREYNOR, DAN JENSEN (PERIODE TAHUN 2013-2016)
}

\author{
Anindita Maditiara \\ Mahasiswa Program Studi S1 Ekonomi Islam-Fakultas Ekonomi dan Bisnis-Universitas Airlangga \\ Email: anindita.maditiara-13@feb.unair.ac.id \\ Dr. M. Nafik H. R., SE., M.SI. \\ Departemen Ekonomi Syariah-Fakultas Ekonomi dan Bisnis-Universitas Airlangga \\ Email: muhammadnafik@feb.unair.ac.id
}

\begin{abstract}
:
The objective of this research is to identify whether there is a difference of the performance of mutual fund shares among Sharpe, Treynor, and Jensen Index (Period 20132016) by analyzing the performance of each sampling stock from Sharia-Protected Mutual Funds. The population of this research is all Sharia-Protected Mutual Funds registered at Bapepam-LK. The data used in this research are monthly Net Asset Value (NAV), Indonesian Sharia Stock index (ISSI), and SUkUk ljarah. The approach that has been used in this research is quantitative with One-Way Anova analysis technique with three variables Sharpe Index (X1), Treynor Index (X2), Jensen Index (X3), as variables that measure the performance of ShariaProtected Mutual Fund.
\end{abstract}

\section{Keywords: Mutual funds Performance, Sharia Protected Mutual Funds, Sharpe, Treynor, Jensen}

\section{PENDAHULUAN Latar Belakang}

Pada masa sekarang, pasar modal merupakan salah satu pilihan bagi para investor untuk menginvestasikan hartanya. Menurut Darmaji dan Fakhruddin (2006:1), Pasar modal (capital market) merupakan suatu pasar untuk berbagai instrumen kevangan jangka panjang yang bisa diperjualbelikan, baik dalam bentuk utang maupun modal sendiri. Perkembangan pasar modal di Indonesia menjadi daya tarik tersendiri bagi para investor untuk menanamkan modalnya di bursa. Investasi pada pasar modal merupakan salah satu cara bagi masyarakat pemodal untuk memperoleh keuntungan dengan cepat. Allah SWT berfirman dalam al-Qur'an surat Luqman ayat 34 :

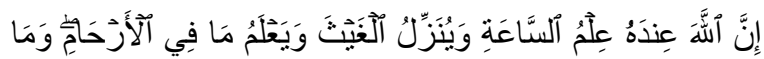

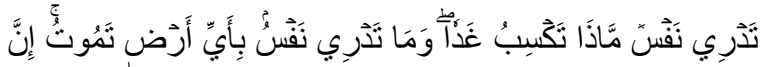

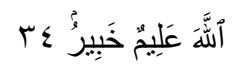

34. Sesungguhnya Allah, hanya pada sisiNya sajalah pengetahuan tentang hari kiamat; dan Dialah Yang menurunkan hujan, dan mengetahui apa yang ada dalam rahim. Dan tiada seorangpun yang dapat mengetahui (dengan pasti) apa yang akan diusahakannya besok. Dan tiada seorangpun yang dapat mengetahui di bumi mana dia akan mati. Sesungguhnya Allah maha Mengetahui lagi Maha Mengenal. (QS. Luqman:34)(Kemenag RI, 2016)

Perkembangan pasar modal syariah, memberikan dampak positif pada perkembangan reksadana syariah.

Tabel 1

Proporsi NAB Reksadana Syariah

Sumber: Otoritas Jasa Keuangan 2016 (Data Diolah)

\begin{tabular}{|c|c|c|}
\hline Tahun & $\begin{array}{c}\text { Jumlah } \\
\text { Reksa Dana } \\
\text { Syariah }\end{array}$ & $\begin{array}{c}\text { NAB Reksa Dana } \\
\text { Syariah (Rp. } \\
\text { Miliar) }\end{array}$ \\
\hline 2011 & 50 & $5.564,79$ \\
\hline 2012 & 58 & $8.050,70$ \\
\hline 2013 & 65 & $9.432,19$ \\
\hline 2014 & 74 & $11.158,00$ \\
\hline 2015 & 93 & $11.019,43$ \\
\hline 2016 & 136 & $14.914,63$ \\
\hline Total & $\mathbf{4 7 6}$ & $\mathbf{6 0 . 1 3 9 , 7 4}$ \\
\hline
\end{tabular}

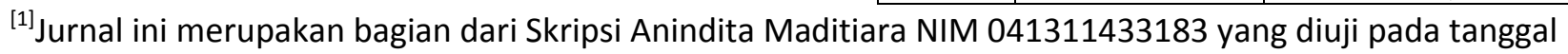
18 Desember 2017 
Maditiara, et al/Jurnal Ekonomi Syariah Teori dan Terapan Vol. 5 No. 11 November 2018: 955-970; KINERJA REKSADANA TERPROTEKSI SYARIAH DENGAN METODE INDEKS SHARPE, TREYNOR, DAN JENSEN (PERIODE 2013-2016)

Dalam penelitian ini, subjek penelitian yang diteliti adalah reksadana terproteksi syariah. Reksadana terproteksi syariah mempunyai sifat yang terbatas. Maksudnya adalah bahwa reksadana ini hanya bisa dibeli dalam jangka waktu dan nominal yang tertentu pula. Biasanya ketika mendapatkan pernyataan efektif, manajer investasi akan membuka masa penawaran reksadana yang lamanya bisa berkisar antara 1 sampai 3 bulan. Salah satu ciri dari reksadana terproteksi syariah adalah underlying reksadana akan di-hold sampai jatuh tempo, hal ini sangat berbeda dengan produk reksadana pendapatan tetap yang akan memperdagangkan underlying reksadana tersebut. Karena perbedaan cara penanganan dalam underlying reksadana, maka reksadana terproteksi syariah hanya bisa dibeli pada saat di awal saja dan tidak bisa dijual sebelum masa jatuh tempo. Sementara jika pada reksadana pendapatan tetap, investor dapat melakukan pembelian dan penjualan underlying reksadana kapan saja. (Rudiyanto:2011)

\section{Rumusan Masalah}

Apakah terdapat perbedaan kinerja reksadana terproteksi syariah periode 20132016 dengan metode indeks Sharpe, treynor, dan Jensen?

\section{Tujuan Penelitian}

Tujuan penelitian ini adalah untuk mengetahui apakah terdapat perbedaan kinerja reksadana terproteksi syariah periode 2013-2016 dengan metode indeks sharpe, treynor, dan Jensen.

\section{LANDASAN TEORI DAN PENGEMBANGAN HIPOTESIS}

Investasi Dalam Islam

Menurut Riyandono (2009:34),

Investasi syariah merupakan suatu pengorbanan sumber daya pada masa sekarang untuk mendapatkan hasil yang lebih besar pada masa yang akan datang, baik secara langsung maupun tidak langsung, seraya tetap berpijak pada prinsip syariah yang menyeluruh (kaffah).

\section{Reksadana Terproteksi Syariah}

Menurut Rudiyanto (2011), reksadana terproteksi adalah salah satu jenis produk reksadana yang karakteristiknya mirip dengan deposito. Reksadana jenis ini memiliki masa jatuh tempo, membagikan keuntungan (dividen) secara periodik, dan biasanya nilai pokok investasi dari investor masih tetap utuh pada saat jatuh tempo. Reksadana terproteksi "berusaha" melindungi nilai pokok investasi para investor dengan cara melakukan strategi investasi secara pasif, caranya dengan membeli obligasi syariah dan memegangnya hingga jatuh tempo.

\section{Nilai Aktiva Bersih (NAB)}

Nilai Aktiva Bersih (NAB) atau sering juga disebut sebagai Net Asset Value (NAV) merupakan alat ukur kinerja reksadana. Nilai aktiva bersih berasal dari nilai portofolio reksadana yang bersangkutan. Nilai Aktiva 
Maditiara, et al/Jurnal Ekonomi Syariah Teori dan Terapan Vol. 5 No. 11 November 2018: 955-970; KINERJA REKSADANA TERPROTEKSI SYARIAH DENGAN METODE INDEKS SHARPE, TREYNOR, DAN JENSEN (PERIODE 2013-2016)

Bersih (NAB) juga merupakan jumlah aktiva setelah dikurangi kewajiban-kewajban yang ada. Sedangkan NAB per Unit Penyerta merupakan jumlah NAB dibagi dengan jumlah nilai Unit Penyerta yang beredar (outstanding) yang telah beredar (dimiliki Investor) pada saat tertentu. (Sudarsono, 2007:207)

\section{Penilaian Kinerja Reksadana}

Salah satu tujuan dari penilaian kinerja portofolio adalah untuk mengetahui dan menganalisis apakah portofolio yang sudah dibentuk dapat meningkatkan kemungkinan tercapainya tujuan investasi dan dapat diketahui portofolio mana yang memiliki kinerja lebih baik.

Untuk melihat kinerja sebuah reksadana, tidak cukup dilihat dari tingkat return yang dihasilkan saja, tetapi diperlukan juga memperhatikan faktorfaktor lain seperti tingkat risiko reksadana tersebut. Untuk mengukur perbandingan tingkat risiko dan return kita dapat menggunakan tiga macam metode yaitu metode Sharpe, metode Treynor, dan metode Jensen (Tandelilin, 2001:324).

\section{Indeks Sharpe}

Indeks Sharpe mendasarkan perhitungannya pada konsep garis pasar modal (capital market line) sebagai patok duga. Semakin tinggi indeks Sharpe suatu portofolio dibanding portofolio lainnya, maka semakin baik kinerja portofolio tersebut. (Tandelilin, 2010:493)
Untuk mengukur indeks Sharpe digunakan persamaan sebaggai berikut: (Tandelilin, 2010:494)

$$
\hat{S}_{p}=\frac{\overline{R_{p}}-\boldsymbol{R f}}{\sigma_{T R}}
$$

Dimana:

$\hat{\mathrm{S}}_{p} \quad=$ Indeks Sharpe reksadana $\mathrm{p}$

$R_{p} \quad=$ Rata-rata Return reksadana p selama periode pengamatan

$R f \quad=$ Rata-rata tingkat Return bebas risiko selama periode pengamatan

$\sigma_{T R} \quad=$ Standar deviasi reksadana p selama periode pengamatan

\section{Indeks Treynor}

Pada indeks Treynor, kinerja portofolio dapat dilihat dengan cara menghubungkan tingkat Return portofolio dengan besarnya risiko dari portofolio tersebut. Asumsi yang digunakan Treynor adalah portofolio sudah terdiversifikasi dengan baik sehingga risiko yang dianggap relevan adalah risiko sistematis (diukur dengan beta). Semakin tinggi indeks Treynor suatu portofolio, maka kinerja portofolio tersebut semakin baik. (Tandelilin, 2010:497) Dengan demikian, indeks Treynor suatu portofolio dalam periode ttertentu dapat dihitung dengan menggunakan persamaan berikut: 
Maditiara, et al/Jurnal Ekonomi Syariah Teori dan Terapan Vol. 5 No. 11 November 2018: 955-970; KINERJA REKSADANA TERPROTEKSI SYARIAH DENGAN METODE INDEKS SHARPE, TREYNOR, DAN JENSEN (PERIODE 2013-2016)

$$
T_{p}=\frac{R_{p}-R f}{\beta_{p}}
$$

Dalam hal ini:

$T_{p} \quad=$ Indeks Treynor reksadana $p$

$R_{n p} \quad=$ Rata-rata Return reksadana

p selama periode pengamatan

Rf = Rata-rata tingkat Return bebas risiko selama periode pengamatan

$\beta_{i} \quad=$ Beta reksadana $i$

\section{Indeks Jensen}

Indeks ini berdasarkan pada konsep security market line (SML) yang merupakan garis yang menghubungkan antara portofolio pasar dengan kesempatan investasi bebas risiko yaitu persaman garis yang melewati titik $(0, R f)$ dan $\left(1, R_{m}\right)$. (Tandelilin, 2010:500)

Persamaan untuk indeks Jensen adalah sebagai berikut:

$$
\left.\hat{\mathrm{J}}_{p}=\overline{R_{p}}-\overline{[R f}+\left(R_{m}-\overline{R f}\right)\right] \beta_{p}
$$

\section{Dalam hal ini:}

$\hat{\mathrm{J}}_{p} \quad=$ Indeks Jensen reksadana $\mathrm{p}$

$R_{p} \quad=$ Rata-rata Return reksadana p selama periode pengamatan

$R_{m} \quad=$ Return pasar

$R f=$ Rata-rata tingkat Return bebas risiko selama periode pengamatan

$\beta_{p} \quad=$ Beta reksadana $p$
$H_{0}$ : Tidak ada perbedaan kinerja reksadana terproteksi syariah periode 2013-2016 dengan Metode Indeks Sharpe, Treynor, dan Jensen.

$H_{1}$ : Ada perbedaan kinerja reksadana terproteksi syariah periode 20132016 antara dengan Metode Indeks Sharpe, Treynor, dan Jensen.

\section{Metodologi Penelitian}

\section{Pendekatan Penelitian}

Pendekatan penelitian ini menggunakan pendekatan kuantitatif. Analisis data yang digunakan bersifat statistik deskriptif. Setelah itu, peneliti melakukan analisis perbandingan dengan alat uji One-Way ANOVA dan f-test menggunakan SPSS sebagai alat statistik.

\section{Identifikasi Variabel}

Variabel yang digunakan dalam penelitian ini adalah sebagai berikut:

1. Kinerja Reksadana Terproteksi Syariah dengan Metode Indeks Sharpe

2. Kinerja Reksadana Terproteksi Syariah dengan Metode Indeks Treynor

3. Kinerja Reksadana Terproteksi Syariah dengan Metode Indeks Jensen

\section{Definisi Operasional Variabel}

1. Tingkat Return Reksadana Terproteksi Syariah

Return reksadana terproteksi syariah merupakan tingkat pengembalian 
Maditiara, et al/Jurnal Ekonomi Syariah Teori dan Terapan Vol. 5 No. 11 November 2018: 955-970; KINERJA REKSADANA TERPROTEKSI SYARIAH DENGAN METODE INDEKS SHARPE, TREYNOR, DAN JENSEN (PERIODE 2013-2016)

reksadana terproteksi syariah yang dihitung dengan persamaan berikut:

$$
R p, t=\frac{V_{E}-V_{B}}{V_{B}}
$$

Keterangan:

$$
\begin{array}{ll}
R p, t=\text { Return reksadana } p \text { pada } \\
\\
\text { periode } \dagger \\
V_{E} \quad=\text { NAB/UP Periode } \dagger \\
V_{B} \quad=\text { NAB/UP Periode } t-1
\end{array}
$$

2. Tingkat Return Bebas Risiko (Risk Free)

Return bebas risiko yaitu tingkat pengembalian yang diwakili oleh tingkat pengembalian sukuk ijarah 1 tahun, dengan cara:

$$
\boldsymbol{R}_{f, t}=\text { Sukuk Ijarah } 1 \text { tahun }
$$

Keterangan:

$$
\begin{aligned}
R_{f, t} & =\text { Return bebas risiko pada } \\
& \text { periode } \dagger
\end{aligned}
$$

\section{Tingkat Risiko Reksadana Terproteksi Syariah}

Standard Deviasi (risiko total) reksadana terproteksi syariah adalah berasal dari variabilitas return yang dihasilkan oleh reksadana, yang diukur dari return bulanan reksadana terproteksi syariah sebagai berikut:

$$
\sigma_{p}=\sqrt{\frac{\sum_{t=1}^{n}\left[R_{p, t}-\bar{R}_{t}\right]^{2}}{n-1}}
$$

Keterangan:

$$
\begin{aligned}
\sigma_{p} & =\text { Standar Deviasi reksadana } \\
& p \\
R_{p, t} & =\text { Return reksadana } \mathrm{p} \text { pada } \\
& \text { periode } \dagger
\end{aligned}
$$

$$
\bar{R}_{t} \quad=\text { Rata-rata return reksadana }
$$

\section{Tingkat Risiko Sistematis}

Beta ( $\beta$ ) adalah parameter yang mengukur volatilitas return reksadana terproteksi syariah terhadap return pasar. Beta dalam penelitian ini adalah perbandingan antara risiko reksadana terproteksi syariah dan risiko pasar.

Beta dapat dihitung dengan menggunakan persamaan sebagai berikut:

$$
\beta_{i}=\frac{\sigma_{i M}}{\sigma_{M^{2}}}
$$

Dimana:

$\beta_{i}=$ Beta Reksadana Terproteksi Syariah

$\sigma_{i M} \quad=$ Kovarian return reksadana terproteksi syariah ke-i dengan return pasar $\sigma_{M^{2}} \quad=$ Varians return pasar

\section{Indeks Sharpe}

Untuk mengukut indeks Sharpe menggunakan persamaan berikut: (Tandelilin, 2010:494)

$$
\hat{\mathrm{S}}_{p}=\frac{\boldsymbol{R}_{p}-\boldsymbol{R f}}{\sigma_{T R}}
$$

Dalam hal ini:

$\hat{S}_{p} \quad=$ Indeks Sharpe reksadana $\mathrm{p}$

$R_{p} \quad=$ Rata-rata Return reksadana p selama periode pengamatan

Rf = Rata-rata tingkat Return bebas risiko selama periode pengamatan 
Maditiara, et al/Jurnal Ekonomi Syariah Teori dan Terapan Vol. 5 No. 11 November 2018: 955-970; KINERJA REKSADANA TERPROTEKSI SYARIAH DENGAN METODE INDEKS SHARPE, TREYNOR, DAN JENSEN (PERIODE 2013-2016)
$\sigma_{T R} \quad=$ Standar deviasi reksadana
p selama periode
pengamatan.

\section{Indeks Treynor}

Untuk mengukur indeks Treynor digunakan persamaan sebagai berikut: (Tandelilin, 20130:494)

$$
T_{p}=\frac{R_{p}-R f}{\beta_{p}}
$$

Dalam hal ini:

$T_{p} \quad=$ Indeks Treynor reksadana $\mathrm{p}$

$R_{p} \quad=$ Rata-rata Return reksadana p selama periode pengamatan

Rf = Rata-rata tingkat Return bebas risiko selama periode pengamatan

$\beta_{p} \quad=$ Beta reksadana $p$

\section{Indeks Jensen}

Persamaan untuk indeks Jenden adalah sebagai berikut: (Tandelilin, 2010:495)

$$
\hat{\mathrm{J}}_{p}=R_{p}-\left[R f+\left(R_{m}-R f\right)\right] \beta_{p}
$$

Dalam hal ini:

$$
\begin{array}{rlr}
\hat{\mathrm{J}}_{p} & =\text { Indeks Jensen reksadana } \mathrm{p} \\
R_{p} & =\text { Rata-rata Return reksadana } \\
& \mathrm{P} \quad \text { selama } \quad \text { periode } \\
& \text { pengamatan } &
\end{array}
$$

$$
\begin{array}{ll}
R_{m} & =\text { Return pasar } \\
R f & =\text { Rata-rata tingkat Return } \\
& \text { bebas risiko selama periode } \\
& \text { pengamatan } \\
\beta_{p} & =\text { Beta reksadana } p
\end{array}
$$

\section{Jenis dan Sumber Data}

Jenis data dalam penelitian ini adalah data sekunder berupa laporan Nilai Aktiva Bersih dari reksadana terproteksi syariah. Data yang digunakan adalah tingkat pengembalian sukuk ijarah tahunan selama periode penelitian.

\section{Populasi dan Sampel}

Populasi pada penelitian ini adalah seluruh reksadana terproteksi syariah yang terdaftar di Bapepam-LK yang didapat dari website www.ojk.go.id

Teknik pengambilan sampel yang digunakan adalah purposive sampling. Beberapa pertimbangan yang diambil adalah sampel yang diambil merupakan reksadana terproteksi sayriah yang terdaftar di Bapepam-LK; reksadana yang selama periode penelitian (tahun 2013-2016) tidak dilikuidasi, tidak bubar, tidak merger, dan tercatat di Bapepam-LK; produk dari perusahaan reksadana terproteksi syariah yang Nilai Aktiva Bersih (NAB) dipublikasikan di media cetak.

\section{Teknik Analisis}


Maditiara, et al/Jurnal Ekonomi Syariah Teori dan Terapan Vol. 5 No. 11 November 2018: 955-970; KINERJA REKSADANA TERPROTEKSI SYARIAH DENGAN METODE INDEKS SHARPE, TREYNOR, DAN JENSEN (PERIODE 2013-2016)

Langkah-langkah yang dilakukan

untuk menganalisis masalah yang telah dirumuskan diawali dengan menghitung return reksadana terproteksi syariah, return bebas risiko, standard deviasi (risiko total), risiko sistematis ( $\beta$ ). Kemudian dilakukan analisis dengan indeks Sharpe, Treynor, dan Jensen.

Tahap berikutnya dilakukan uji normalitas dengan Kolomogorov-Smirnov. Data akan terdistribusi normal saat nilai sig > 0,05 , sedangkan saat nilai sig $<0,05$ maka data berdistribusi tidak normal. Kemudian untuk menguji hipotesis yang sudah dibuat dilakukan uji One-Way ANOVA. Jika F hitung > F tabel 0,05 maka Ho ditolak, sedangkan jika $F$ hitung < F tabel 0,05, maka Ho diterima.

Untuk data yang tidak terdistribusi normal, dilakukan uji kruskal wallis. Pengambilan keputusan pada uji ini ketika nillai sig > 0,05, maka Ho diterima, sedangkan Ho ditolak saat nilai sig <0,05.

\section{HASIL DAN PEMBAHASAN}

\section{Deskripsi Hasil Penelitian}

1. Deskripsi Hasil Penelitian Nilai Aktiva Bersih (NAB) Reksadana Terproteksi Syariah
Tabel 2

NAB Per Unit Penyertaan 6 reksadana Terproteksi Syariah

Periode Tahun 2013-2016

\begin{tabular}{|c|c|c|c|c|}
\hline BULAN & BSPF 1 & $\begin{array}{c}\text { BNI- } \\
\text { AMPSS } \\
1\end{array}$ & DPS II & ETS \\
\hline Sep-13 & 1027.46 & 1018.72 & 1003.21 & \\
\hline Oct-13 & 1027.83 & 1018.71 & 1003.57 & 1003.45 \\
\hline Nov-13 & 1027.74 & 1018.25 & 1003.63 & 1003.27 \\
\hline Dec-13 & 1027.99 & 1018.39 & 1003.99 & 1003.17 \\
\hline Jan-14 & 1028.23 & 1018.91 & 1004.34 & 1003.47 \\
\hline Feb-14 & 1028.12 & 1018.63 & 1004.38 & 1003.57 \\
\hline Mar-14 & 1027.79 & 1018.26 & 1004.13 & 1003.5 \\
\hline Apr-14 & 1028.25 & 1018.36 & 1004.99 & 1004.09 \\
\hline May-14 & 1028.25 & 1018.28 & 1005.1 & 1004.2 \\
\hline Jun-14 & 1028.48 & 1018.35 & 1005.34 & 1004.42 \\
\hline Jul-14 & 1027.81 & 1018.82 & 1004.68 & 1003.77 \\
\hline Aug-14 & 1028.65 & 1019.51 & 1005.53 & 1004.63 \\
\hline Sep-14 & 1029.08 & 1019.73 & 1005.96 & 1004.97 \\
\hline Oct-14 & 1029.3 & 1019.72 & 1006.24 & 1005.14 \\
\hline Nov-14 & 1029.03 & 1019.27 & 1006.05 & 1004.85 \\
\hline Dec-14 & 1029.41 & 1019.42 & 1006.46 & 1005.18 \\
\hline Jan-15 & 1029.67 & 1019.41 & 1006.68 & 1005.45 \\
\hline Feb-15 & 1029.41 & 1018.99 & 1006.4 & 1005.38 \\
\hline Mar-15 & 1029.67 & 1019.28 & 1006.76 & 1005.89 \\
\hline Apr-15 & 1029.68 & 1019.27 & 1006.83 & 1006.06 \\
\hline May-15 & 1029.57 & 1019.06 & 1006.77 & 1006.05 \\
\hline Jun-15 & 1029.96 & 1019.28 & 1007.17 & 1006.46 \\
\hline Jul-15 & 1030.21 & 1019.84 & 1007.38 & 1006.74 \\
\hline Aug-15 & 1030.41 & 1020.02 & 1008 & 1007.03 \\
\hline Sep-15 & 1030.38 & 1019.91 & 1008.1 & 1007.14 \\
\hline Oct-15 & 1030.5 & 1019.83 & 1008.19 & 1007.23 \\
\hline Nov-15 & 1030.75 & 1019.88 & 1008.47 & 1007.42 \\
\hline Dec-15 & 1030.85 & 1019.75 & 1008.63 & 1007.44 \\
\hline Jan-16 & 1030.94 & 1020.27 & 1008.77 & 1007.43 \\
\hline Feb-16 & 1029.04 & 1020.34 & 1011.35 & 1007.6 \\
\hline Mar-16 & 1031.41 & 1020.46 & 1009.34 & 1007.84 \\
\hline Apr-16 & 1031.33 & 1020.28 & 1009.34 & 1007.48 \\
\hline May-16 & 1029.38 & 1020.53 & 1009.32 & 1007.47 \\
\hline Jun-16 & 1031.76 & 1020.44 & 1010.18 & 1007.27 \\
\hline Jul-16 & 1031.68 & 1019.89 & 1010.18 & 1006.9 \\
\hline Aug-16 & 1032.17 & 1020.49 & 1010.72 & 1007.14 \\
\hline Sep-16 & 1032.26 & 1020.34 & 1010.85 & 1007 \\
\hline Oct-16 & 1032.52 & 1020.33 & 1011.14 & 1006.92 \\
\hline Nov-16 & 1032.71 & 1020.02 & 1011.26 & 1006.67 \\
\hline Dec-16 & 1032.71 & 1020.01 & 1011.4 & 1006.42 \\
\hline
\end{tabular}


Maditiara, et al/Jurnal Ekonomi Syariah Teori dan Terapan Vol. 5 No. 11 November 2018: 955-970; KINERJA REKSADANA TERPROTEKSI SYARIAH DENGAN METODE INDEKS SHARPE, TREYNOR, DAN JENSEN (PERIODE 2013-2016)

\begin{tabular}{|c|c|c|c|}
\hline LPS I & MPDSS 2 & 1159.93 & 1029.21 \\
\hline 1153.39 & 1020.74 & 1160.27 & 1029.67 \\
\hline 1153.13 & 1022.56 & 1160.33 & 1027.43 \\
\hline 1152.4 & 1024.08 & 1159.02 & 1030.02 \\
\hline 1152.21 & 1026.01 & 1158.02 & 1030.04 \\
\hline 1151.98 & 1025.38 & 1149.37 & 1030.07 \\
\hline 1151.48 & 1025.31 & 1156.98 & 1030.27 \\
\hline 1151.25 & 1025.12 & 1164.55 & 1030.32 \\
\hline 1151.91 & 1025.8 & 1163.82 & 1030.3 \\
\hline 1151.87 & 1025.99 & 1162.73 & 1030.44 \\
\hline 1151.87 & 1027.12 & 1162.73 & 1028.16 \\
\hline 1150.56 & 1026.45 & 1153.26 & 1030.45 \\
\hline 1151.78 & 1027.42 & 1152.96 & 1030.76 \\
\hline 1152.27 & 1027.9 & 1152.29 & 1030.79 \\
\hline 1152.51 & 1028.18 & 1151.13 & 1030.79 \\
\hline 1151.93 & 1027.98 & 1150.6 & 1031.22 \\
\hline 1160.25 & 1028.38 & 1100.0 & \\
\hline 1160.27 & 1028.59 & 1149.71 & 1031.31 \\
\hline 1159.64 & 1028.49 & 1148.87 & 1031.51 \\
\hline 1160.35 & 1029.01 & 1148.05 & 1029.26 \\
\hline 1160.29 & 1029.2 & 1138.96 & 1031.56 \\
\hline
\end{tabular}

Sumber: Data Diolah

Pada tabel 2 diatas, menunjukkan bahwa Nilai Aktiva Bersih Per Unit Penyertaan ke enam Reksadana memiliki nilai kenaikan NAB/UP yang berbeda-beda. Dari tabel NAB/UP Bahana Syariah Protected Fund I (BSPF-I) periode 2013-2016 tidak mengalami perubahan yang cukup signifikan, yaitu berada pada kisaran angka 1027,99 hingga mencapai angka 1032,71. Pada BNIAM Proteksi Syariah Grenada Seri I (BNI-AMPSGS I) periode 2013-2016 juga tidak mengalami kenaikan yang cukup signifikan, yaitu berada pada kisaran angka 1018,39 hingga mencapai angka 1032,71 pada akhir periode 2016.

Kemudian NAB/UP dari Danareksa Proteksi Syariah ॥ (DPS II) dan Emco

Terproteksi Syariah (ETS) juga tidak mengalami perubahan yang cukup signifikan, tetapi kedua perusahaan ini memiliki nilai NAB/UP yang lebih rendah dibandingkan dengan ke empat Reksadana lainnya. Pada Danareksa Proteksi Syariah II nilai NAB/UP berada pada kisaran angka 1003,99 hingga mencapai angka 1011,4, sedangkan nilai NAB/UP Emco Terproteksi Syariah berada pada kisaran angka 1003,17 hinggga mencapai angka terbesar yaitu 1007,84. Nilai NAB/UP Lautandhana Proteksi Syariah I berada pada kisaran angka 1152,21 hingga mencapai angka 1163.82. pada Lautandhana Proteksi Syariah । tidak mengalami kenaikan yang cukup signifikan pada periode tahun 2013-2015, tetapi pada pertengahan tahun 2016 mengalami penurunan yang cukup signifikan, pada bulaun januari 2016 mencapai angka 1163,82 kemudian terus menurun hingga akhir periode 2016 menjadi sebesar 1138,96. Hal ini disebabkan oleh penurunan kinerja dari perusahaan Lautandhana Proteksi Syariah I yang menyebabkan para investor menarik dananya. Kemudian nilai NAB/UP pada Mandiri Proteted Dynamic Syariah Seri II tidak mengalami perubahan yang cukup signifikan, yaitu berada pada kisaran angka 1026,01 hingga mencapai angka 1031,56.

\section{Deskripsi Hasil Penelitian Return Pasar Periode Tahun 2013-2016}


Maditiara, et al/Jurnal Ekonomi Syariah Teori dan Terapan Vol. 5 No. 11 November 2018: 955-970; KINERJA REKSADANA TERPROTEKSI SYARIAH DENGAN METODE INDEKS SHARPE, TREYNOR, DAN JENSEN (PERIODE 2013-2016)

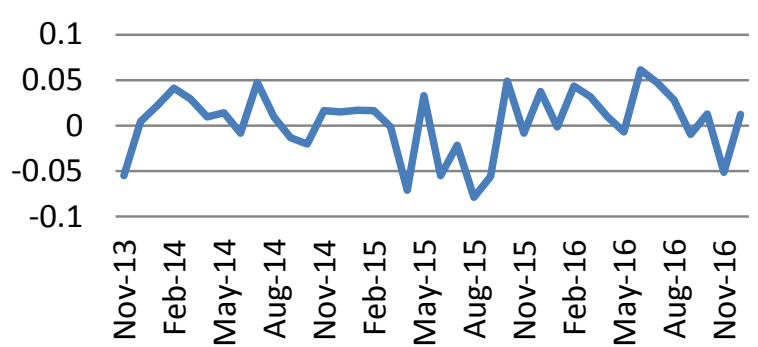

Sumber: Data Diolah

Gambar 1

Return Pasar Periode Tahun 2013-2016

Pada gambar 1 diatas, menggambarkan pergerakan nilai return pasar dari tahun 2013-2016. Return pasar ini didapat dari nilai Indeks Saham Syariah Indonesia (ISSI) periode tahun 2013-2016, dimana pergerakan nilai dari Indeks Saham Syariah (ISSI) relatif stabil pada periode 2013 hingga pada awal tahun 2015 dan mengalami penurunan nilai ISSI yang cukUp signifikan pada pertengahan tahun 2015 hingga pada awal tahun 2016.

3. Deskripsi Hasil Penelitiian Return Bebas Risiko (Rf)

Tabel 3

Nilai Return Bebas Risiko Tahun 20132016

\begin{tabular}{|c|c|}
\hline Tahun & $\begin{array}{c}\text { Return Bebas } \\
\text { Risiko (Rf) }\end{array}$ \\
\hline 2013 & 0.07825 \\
\hline 2014 & 0.07825 \\
\hline 2015 & 0.07825 \\
\hline 2016 & 0.07825 \\
\hline
\end{tabular}

Sumber: Data Diolah

Pada tabel 3 diatas nilai return bebas risiko (risk free) pada tahun 20132016 yang digunakan dalam penelitian ini sama, yaitu diambil rata-rata dari tingkat pengembalian ke empat periode pada sukuk ritel Negara.

4. Deskripsi Hasil Penelitiian Return Realisasi (Rp) Reksadana Terproteksi Syariah Tahun 2013-2016

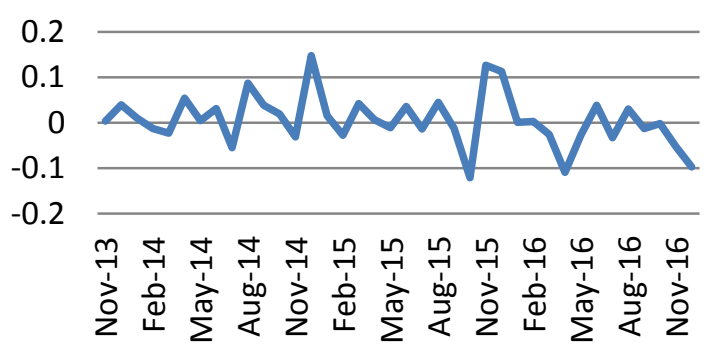

Sumber: Data Dlolah Gambar 2

Return Realisasi (Rp) Reksadana Terproteksi Sayriah Tahun 2013-2016

Pada gambar 2 menggambarkan return realisasi (Rp) pada reksadana terproteksi syariah mengalami perubahan yang cukup signifikan.

5. Deskripsi Hasil Penelitiian Nilai Beta Saham Periode Penelitian Tahun 20132016

Tabel 4

Beta ( $\beta$ ) selamaPeriode Penelitian (Tahun 2013-2016)

\begin{tabular}{|c|c|c|c|}
\hline \multirow[b]{2}{*}{ Bulan } & Beta ( $\beta$ ) & \multirow[b]{2}{*}{ Bulan } & Beta ( $\beta$ ) \\
\hline & $\begin{array}{c}\text { Periode } \\
\text { 2013-2016 }\end{array}$ & & $\begin{array}{c}\text { Periode } \\
\text { 2013-2016 }\end{array}$ \\
\hline Nov-13 & -0.612873 & & \\
\hline Dec-13 & -1.5 & & 80 \\
\hline Jan-14 & -1.56 & & 301 \\
\hline Feb-14 & -1.76 & & 28 \\
\hline Mar-14 & -1.12 & Nov-15 & 375 \\
\hline Apr-14 & -1.917808 & Dec-15 & -4.691092 \\
\hline May-14 & -1.296723 & & -1.001131 \\
\hline Jun-14 & -1.261301 & Feb-16 & -2.309537 \\
\hline
\end{tabular}


Maditiara, et al/Jurnal Ekonomi Syariah Teori dan Terapan Vol. 5 No. 11 November 2018: 955-970; KINERJA REKSADANA TERPROTEKSI SYARIAH DENGAN METODE INDEKS SHARPE, TREYNOR, DAN JENSEN (PERIODE 2013-2016)

\begin{tabular}{|c|c|c|c|} 
Jul-14 & -0.765528 & Mar-16 & -1.124164 \\
\hline Aug-14 & -2.409971 & Apr-16 & 0.447358 \\
\hline Sep-14 & -1.274333 & May-16 & -0.597940 \\
\hline Oct-14 & -0.987600 & Jun-16 & -6.918060 \\
\hline Nov-14 & -0.759658 & Jul-16 & -1.445394 \\
\hline Dec-14 & -3.589472 & Aug-16 & -2.163024 \\
\hline Jan-15 & -1.535413 & Sep-16 & -0.746511 \\
\hline Feb-15 & -0.820440 & Oct-16 & -1.175939 \\
\hline Mar-15 & -1.512350 & Nov-16 & -0.199259 \\
\hline Apr-15 & -0.565130 & Des-16 & 0.279701 \\
\hline May-15 & -1.482513 & \multicolumn{3}{|c}{} \\
\cline { 1 - 1 } Jun-15 & -0.856353 & \multicolumn{2}{|c}{} \\
\cline { 1 - 2 } & &
\end{tabular}

Sumber: finance.yahoo.com (Data Diolah)

Pada tabel 4 diatas, meununjukkan bahwa beta cenderung < 1 yang berarti bahwa tingkat keuntungan saham i meningkat lebih kecil dibandingkan dengan tingkat keuntungan keseluruhan saham di pasar. Ini menandakan bahwa risiko sistematis saham lebih kecil dibandingkan dengan risiko sistematis pasar. (Husnan, 2001:168)

\section{Deskripsi Hasil Penelitiian Indeks Sharpe}

Kinerja Reksadana Terproteksi Syariah dengan Metode Indeks Sharpe Indeks Sharpe mendasarkan perhitungannya pada konsep garis pasar modal (capital market line) sebagai patok duga, caranya yaitu dengan membagi premi risiko portofolio (sama dengan selisih rata-rata tingkat keuntungan portofolio dengan ratarata bunga bebas risiko) dengan standar deviasinya (risiko total). Hasil

rata-rata dari perhitungan reksadana terproteksi syariah pada metode Indeks Sharpe bernilai $-0,033213$.

7. Deskripsi Hasil Penelitiian Indeks Treynor Kinerja Reksadana Terproteksi Syariah dengan Metode Indeks Treynor merupakan perbandingan rata-rata antara selisih return portofolio dan return bebas risiko dengan beta portofolio. Semakin tinggi indeks Treynor suatu portofolio, maka kinerja portofolio tersebut semakin baik. Hasil rata-rata dari perhitungan reksadana terproteksi syariah pada metode Indeks Treynor bernilai 0,066005, dimana hasil rata-rata pada perhitungan Indeks Treynor lebih besar dibandingkan dengan kedua jenis perhitungan Indeks Sharpe dan Indeks Jensen.

\section{Deskripsi Hasil Penelitiian Indeks Jensen}

Kinerja Reksadana Terproteksi Syariah dengan Metode Indeks Jensen merupakan selisih antara average return dengan minimum rate return. Hasil rata-rata dari perhitungan reksadana terproteksi syariah pada metode Indeks Jensen bernilai 0,029208.

\section{Analisis Uji Asumsi ANOVA}

\section{Uji Normalitas}

Tabel 5

Uji Normalitas

\begin{tabular}{|l|r|r|r|}
\hline & SHARPE & TREYNOR & \multicolumn{1}{|c|}{ JENSEN } \\
\hline $\begin{array}{l}\text { Kolmogorov } \\
\text {-Smirnov }\end{array}$ & 2.315 & .676 & .543 \\
\hline
\end{tabular}


Maditiara, et al/Jurnal Ekonomi Syariah Teori dan Terapan Vol. 5 No. 11 November 2018: 955-970; KINERJA REKSADANA TERPROTEKSI SYARIAH DENGAN METODE INDEKS SHARPE, TREYNOR, DAN JENSEN (PERIODE 2013-2016)

\begin{tabular}{|l|l|l|l|}
$\begin{array}{l}\text { Asymp. Sig. } \\
\text { (2-tailed) }\end{array}$ & .000 & .751 & .930 \\
\hline
\end{tabular}

a. Test distribution is Normal

Sumber: Data Diolah

Pada tabel 5 diatas, dapat dilihat hasil output SPSS 16.0 menunjukkan bahwa tingkat signifikansi ketiga variabel >0,05. Kesimpulan dari hasil uji normalitas Kolmogorov-Smirnov test diatas adalah bahwa data penelitian ini memenuhi asumsi normalitas.

\section{Pengujian Hipotesis}

\section{Uji One-Way ANOVA}

Tabel 6 Uji One-Way ANOVA

\begin{tabular}{|l|r|r|r|}
\hline & \multicolumn{1}{|c|}{ df } & F & Sig. \\
\hline $\begin{array}{l}\text { Between } \\
\text { Groups }\end{array}$ & 2 & .321 & .726 \\
Within Groups & 111 & & \\
Total & 113 & & \\
\hline
\end{tabular}

Sumber: Data Diolah

Pada tabel 6 diatas, menunjukkan bahwa dari hasil uji One-way ANOVA terlihat bahwa tingkat signifikansi 0,726 $>0,05$ yang berarti secara general tidak ada perbedaan dari indeks Sharpe, Treynor, dan Jensen dalam menganalisis kinerja reksadana terproteksi syariah pada periode November 2013 - Desember 2016. Selanjutnya yang dapat dilihat adalah nilai $F$ hitung. $F$ hitung menunjukkan nilai
0,321 yang selanjutnya dibandingkan dengan $\mathrm{F}$ tabel pada tingkat signifikansi 0,05 yaitu 3,08

\section{Pembahasan}

1. Kinerja Reksadana Terproteksi Syariah Periode 2013-2016 dengan Indeks Sharpe

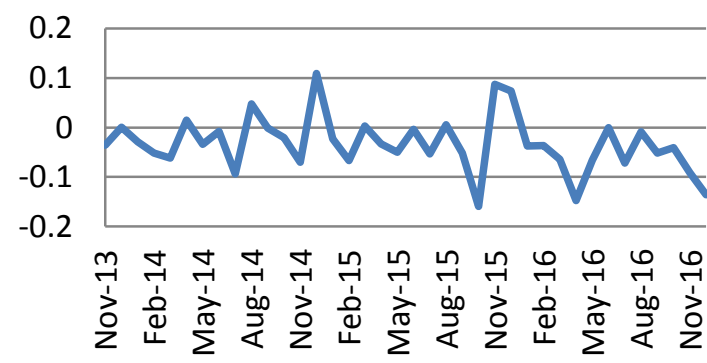

Sumber: Data Diolah

Gambar 3

Kinerja Reksadana Terproteksi Syariah (Indeks Sharpe)

Pada gambar 3 diatas, menggambarkan kinerja dari reksadana terproteksi syariah dengan menggunakan indeks Sharpe periode tahun 2013 sampai dengan tahun 2016 menunjukkan kisaran -0,035823 sampai 0,087152, hal tersebut mengandung arti bahwa fluktuasi harga pada ke-38 bulan reksadana terproteksi syariah cenderung fluktiatif dan menjadikan return yang didapat relatif tidak stabil dan memiliki prospek pertumbuhan yang tidak cukup baik.

\section{Kinerja Reksadana Terproteksi Syariah Periode 2013-2016 dengan Indeks Treynor}


Maditiara, et al/Jurnal Ekonomi Syariah Teori dan Terapan Vol. 5 No. 11 November 2018: 955-970; KINERJA REKSADANA TERPROTEKSI SYARIAH DENGAN METODE INDEKS SHARPE, TREYNOR, DAN JENSEN (PERIODE 2013-2016)

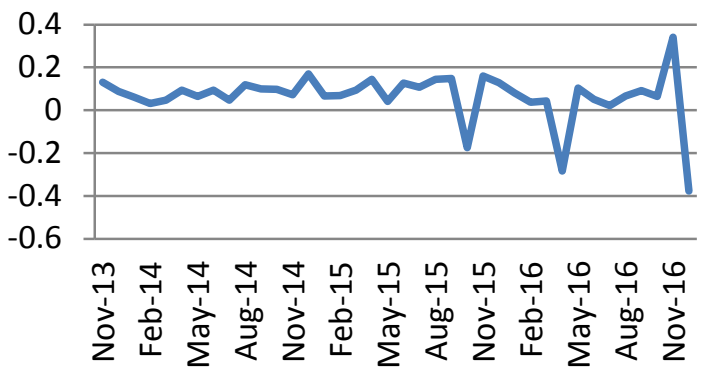

Sumber: Data Diolah

Gambar 4

Kinerja Reksadana Terproteksi Syariah (Indeks Treynor)

Pada gambar 4 diatas, menggambarkan bahwa dari hasil perhitungan indeks Treynor, kinerja reksadana terproteksi syariah periode tahun 2013 sampai dengan tahun 2016 menunjukkan kisaran 0,088239 sampai dengan 0,147385, hal ini mengandung arti bahwa fluktuasi harga tersebut sangat fluktuatif dan terdapat banyak perubahan yang signifikan sehingga relatif kurang stabil.

3. Kinerja Reksadana Terproteksi Syariah Periode 2013-2016 dengan Indeks Jensen

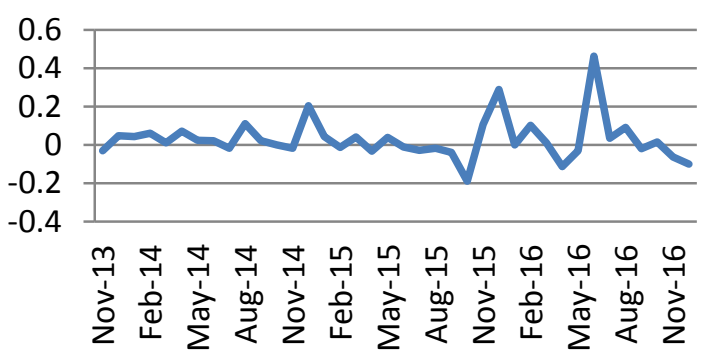

Sumber: Data Diolah

Gambar 5

Kinerja Reksadana Terproteksi Syariah (Indeks Jensen)
Pada gambar 5 diatas, menggambarkan bahwa kinerja reksadana terproteksi syariah periode 2013- 2016 menunjukkan kisaran angka 0,046931 hingga mencapai angka 0,2888828 . Hal ini menunjukkan bahwa pergerakan nilai dari reksadana terproteksi syariah dengan menggunakan indeks Jensen relative stabil dibandingkan dengan kedua indeks lainnya (Sharpe dan Treynor).

\section{Perbandingan Kinerja Reksadana Terproteksi Syariah Periode 2013-2016 Antara Indeks Sharpe, treynor, dan Jensen}

Berdasarkan hasil analisis kinerja reksadana terproteksi syariah, angka indeks dengan menggunakan metode Sharpe berada pada kisaran kisaran 0,035823 sampai 0,087152. Kemudian untuk angka indeks dengan menggunakan metode Treynor berada pada kisaran 0,088239 sampai dengan 0,147385 . Sedangkan angka indeks dengan menggunakan metode Jensen pada kisaran 0,046931 hingga mencapai angka 0,2888828. Masingmasing metode kinerja reksadana terproteksi syariah memiliki dasar angka yang relatif tidak dapat dibandingkan secara langsung satu dengan yang lainnya mengingat metode pengukurannya adalah berbedabeda. Tujuan dari penelitian ini adalah untuk mengetahui apakah ketiga metode pengukuran kinerja tersebut 
Maditiara, et al/Jurnal Ekonomi Syariah Teori dan Terapan Vol. 5 No. 11 November 2018: 955-970; KINERJA REKSADANA TERPROTEKSI SYARIAH DENGAN METODE INDEKS SHARPE, TREYNOR, DAN JENSEN (PERIODE 2013-2016)

memiliki perbedaan yang signifikan atau tidak dalam menganalisis kinerja reksadana terproteksi syariah periode 2013-2016.

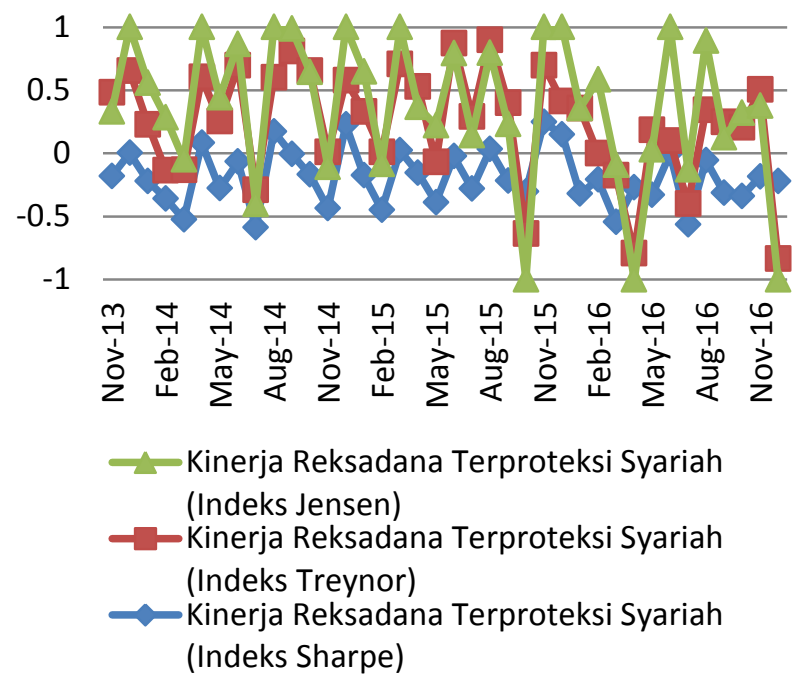

Sumber: Data Diolah

Gambar 6

Kinerja Reksadana Terproteksi

Syariah Periode 203-2016 Anatar Indeks

Sharpe, Treynor, dan Jensen

Berdasarkan uji One-way Anova

dapat diketahui bahwa kinerja reksadana terproteksi syariah periode 2013-2016 berdasarkan indeks Sharpe, Treynor, dan Jensen terbukti tidak memiliki perbedaan. Hal ini dikarenakan berdasar pada pengujian hasil yang didapatkan tidak signifikan dengan nilai 0,726 (0,726>0,05). Untuk uji parsial yaitu mengetahui perbedaan antar variabel secara individu, hasil uji Post-hoc turkey membuktikan bahwa diantara indeks Sharpe dan Treynor tidak memiliki perbedaan karena hasilnya menunjukkan tidak signifikan pada tingkat
$0,755(0,755>0,05)$. Kemudian pada indeks Sharpe dan Jensen juga tidak memiliki perbedaan, hal ini dikarenakan tidak signifikan pada tingkat $0,781 \quad(0,781>0,05)$. Pada uji beda antara indeks Treynor dan Jensen memberikan kesimpulan yang sama, yaitu tidak signifikan pada tingkat 0,999 $(0,999>0,05)$.

\section{SIMPULAN}

Berdasarkan hasil ppenelitian dan hasil pembahasan pada bab sebelumnya, maka kesimpulan yang dapat diambil adalah sebagai berikut:

Bahwa Kinerja Reksadana Terproteksi Syariah (Periode 2013-2016) dengan menggunakan metode indeks Sharpe, Treynor, dan Jensen secara keseluruhan tidak terdapat perbedaan. Sehingga dari ketiga indeks tersebut bisa digunakan untuk mengukur kinerja dari Reksadana Terproteksi Syariah.

Saran yang direkomendasikan adalah:

1. Dengan dapat digunakan untuk menghitung kinerja suatu portofolio antara indeks Sharpe, Treynor, dan Jensen maka pilihan kembali diserahkan kepada para investor, apakah ingin menggunakan risiko yang tidak sistematik (indeks Sharpe) sebagai dasar keputusan untuk investasinya, ataukah risiko sistematik yang bertujuan untuk memperhitungkan antara risiko reksadana dan risiko pasar (indeks 
Maditiara, et al/Jurnal Ekonomi Syariah Teori dan Terapan Vol. 5 No. 11 November 2018: 955-970; KINERJA REKSADANA TERPROTEKSI SYARIAH DENGAN METODE INDEKS SHARPE, TREYNOR, DAN JENSEN (PERIODE 2013-2016)

Treynor), atau mendasarkan pada kemungkinan tingkat pengembalian yang akan diperoleh investor (indeks Jensen).

2. Bagi investor muslim yang ingin menginvestasikan dananya pada sektor halal maka reksadana terproteksi syariah bisa dijadikan salah satu alternatif investasi. Diharapkan dengan adanya penelitian ini semakin meyakinkan para investor untuk berinvestasi pada reksadana khususnya reksadana terproteksi syariah dikarenakan penelitian ini membuktikan bahwa reksadana terproteksi syariah telah terdiversifikasi dengan baik. Selain itu para investor hendaknya mempertimbangkan pada faktor Indeks Saham Syariah Indonesia (ISSI), tingkat pengembalian pada Sukuk ljarah karena keduanya memiliki pengaruh terhadap kinerja reksadana terproteksi syariah.

3. Bagi penelitian selanjutnya, diharapkan tidak hanya membandingkan antara ketiga indeks dalam menganalisis kinerja reksadana terproteksi syariah namun juga beberapa jenis indeks perhitungan kinerja dan reksadana lainnya seperti reksadana pendapatan tetap dan reksadana campuran. Dalam hal ini mengingat jenis reksadana syariah bukan hanya reksadana terproteksi saja namun ada instrumen-instrumen lainnya. Diharapkan penelitian selanjutnya juga bisa memasukkan dua indeks lainnya dalam perhitungan kinerja. Dalam hal ini juga penting mengingat reksadana syariah tidak hanya dipengaruhi oleh faktor-faktor ekonomi saja, tetapi juga dipengaruhi oleh faktor-faktor nonekonomi.

4. Bagi para akademisi diharapkan penelitian ini bisa dijadikan salah satu referensi dalam performa reksadana terproteksi syariah dan juga mengenai tiga dari beberapa indeks perhitungan kinerja yang umum digunakan yaitu indeks Sharpe, Treynor, dan Jensen, serta dapat memberikan informasi dan pemhaman yang lebih banyak mengenai perbedaan diantara ketiga indeks tersebut dalam hal menganalisis suatu kinerja portofolio khususnya reksadana terproteksi syariah.

\section{DAFTAR PUSTAKA}

Darmadji \& Fakhruddin, 2011, Pasar Modal di Indonesia, edisi 3, Salemba Empat, Jakarta.

Husnan, Suad. 2001. Dasar-dasar Teori Portofolio dan Analisis Sekuritas. Edisi II: Yogyakarta: UPP-AMP-YKPN.

KEMENAG, 2016. Al-Quran dan terjemahannya. Jakarta: KEMENAG

Otoritas Jasa Keuangan. 2014. Regulasi Peraturan

OJK. 
Maditiara, et al/Jurnal Ekonomi Syariah Teori dan Terapan Vol. 5 No. 11 November 2018: 955-970; KINERJA REKSADANA TERPROTEKSI SYARIAH DENGAN METODE INDEKS SHARPE, TREYNOR, DAN JENSEN (PERIODE 2013-2016)

(http://www.ojk.go.id, diakses 15 Maret 2017).

Riyandono. 2008. Bursa Efek dan Investasi

Syariah. Jakarta: Serambi.

Rudiyanto. 2011. Reksa Dana untuk Pemula. Jakarta: Elex media Komputindo

Sudarsono, Heri. 2007. Bank dan Lembaga Keuangan Syariah (Deskripsi dan Ilustrasi). Edisi Kedua. Yogyakarta: Ekonisia.

Tandelilin, Eduardus. 2001. Analisis Investasi dan Manajemen Portofolio. Yogyakarta: BPFE.

Tandelilin, Eduardus. 2010. Portofolio dan Investasi. Yogyakarta: Kanisius 